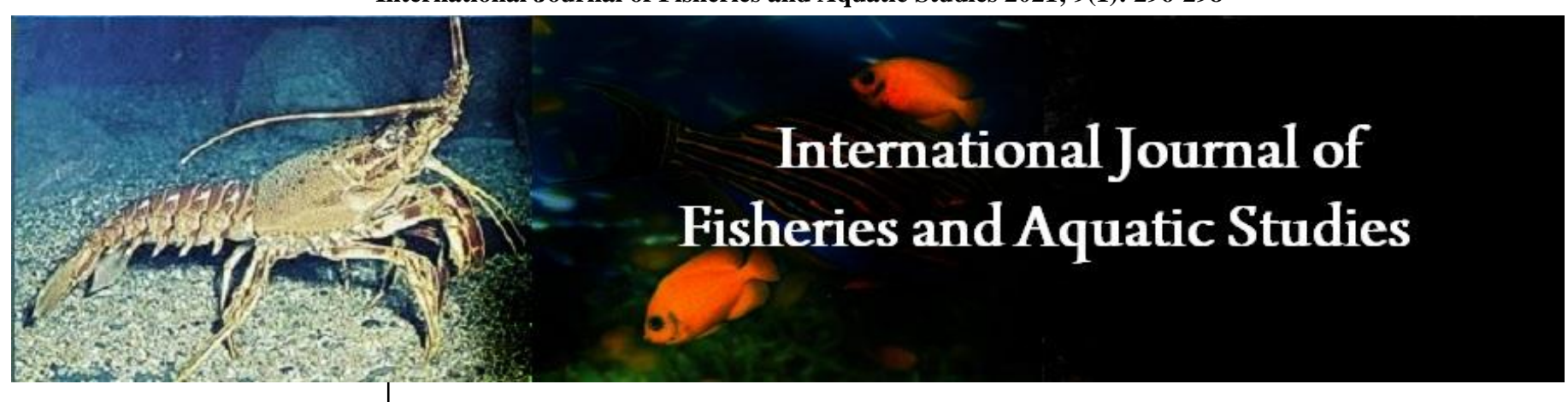

E-ISSN: 2347-5129

P-ISSN: 2394-0506

(ICV-Poland) Impact Value: 5.62

(GIF) Impact Factor: 0.549

IJFAS 2021; 9(1): 296-298

(C) 2021 IJFAS

www.fisheriesjournal.com

Received: 10-11-2020

Accepted: 12-12-2020

Sudarshan R Markad

Department of Zoology,

Nowrosjee Wadia College, Pune,

Maharashtra, India

Akhila S Pillai

Department of Zoology,

Nowrosjee Wadia College, Pune,

Maharashtra, India

\section{Study of diversity of fresh water Molluscs from Ujani wetland, Maharashtra, India}

\author{
Sudarshan R Markad and Akhila S Pillai
}

DOI: https://doi.org/10.22271/fish.2021.v9.i1d.2414

\section{Abstract}

The objectives of the present study were to explore the diversity of mollusc's fauna at different habitats. Molluscs are considered the most diverse and dominant benthic fauna both from lentic and lotic aquatic ecosystems. Present study is an attempt to study diversity of fresh water molluscs from Ujani wetland area, Indapur, Pune, Maharashtra. In present study, 20 species belong to 11 genera and 02 classes were recorded. 11 species belong to class gastropods and 09 species from class Bivalvia. Thus, family Unionidae was the most dominant family exploring 30\% of species. Survey was done from April 2020 to September 2020 during day time from 8 A.M. to 6 P.M. every weekend.

Keywords: Ujani wetland, molluscs diversity, Maharashtra, fresh water

\section{Introduction}

Mollusca is a second largest phylum in invertebrate, found in various habitat and are divided into freshwater, marine and terrestrial forms. The Molluscs are soft bodied animals which play an important role in water ecosystem. The phylum Mollusca have a large group of animals having varied size, shape, habits \& occupy different environment ${ }^{[1]}$. which live in fresh water habitats, both lotic (flowing water) such as rivers, streams, canals, springs and cave streams (stygobite species) and lentic (still water) such as lakes, ponds and ditches. The freshwater molluscs have a shell, in which the soft parts are enclosed. Most species can be suitably recognised by their shell characters.

Molluscans are the environment as well as bio-indicators and the play a very important role in maintaining aquatic ecosystem by recycling nutrients and surviving as nutrition for certain aquatic organisms. Fresh water molluscs play a significant role in aquatic ecosystem, and some of them are edible. Also, they serve an important source of food for other animals i.e., fishes, birds and mammals even for human being. In the age of global decline of biodiversity, it is necessary to study the present status of different biota. The taxonomic study of Indian fresh water molluscs has been done by Zoological Survey of India ${ }^{[1,2,3,4]}$.

The main objective of the present study was to document the molluscan diversity of the freshwater from the Ujani wetland area. The identification, taxonomic account and distribution of molluscs found in freshwater reservoirs will serve to keep complete record for further study.

\section{Materials and Methods}

\section{a. Study area}

Indapur taluka comes under the Pune district, Maharashtra situated between $18^{\circ} 7^{\prime} 1.7040^{\prime \prime} \mathrm{N}$ latitude. and $75^{\circ} 1^{\prime} 26.1048^{\prime \prime}$ E. longitude. The Ujani wetland is a manmade wetland that into existence in June 1980. It was formed because the construction of Ujani dam across the river Bhima. It is named after Ujani village on the border of Solapur Ahmednagar and Pune districts of Maharashtra. Wetland area situated about $120 \mathrm{~km}$ away from Pune.

The present study was conducted from April 2020 to September 2020 at different study sites of Ujani wetland region District-Pune, Maharashtra.

Molluscan shells were collected from five sampling stations

A. Bighwan (10km)
Corresponding Author: Department of Zoology, Nowrosjee Wadia College, Pune, Maharashtra, India 
B. Kumbhargao $(3 \mathrm{~km})$

C. Palasdev $(7 \mathrm{~km})$

D. Madanwadi $(2 \mathrm{~km})$

E. Shirsodi $(2 \mathrm{~km})$

\section{b. Collection of molluscan Shells}

Collected shells we had clean with water and sun dried. These dried shells then we had pack in plastic pouches and brough to the laboratory for further identification. The molluscs were identified by using Handbook of Freshwater Molluscs of India $[2,5]$.

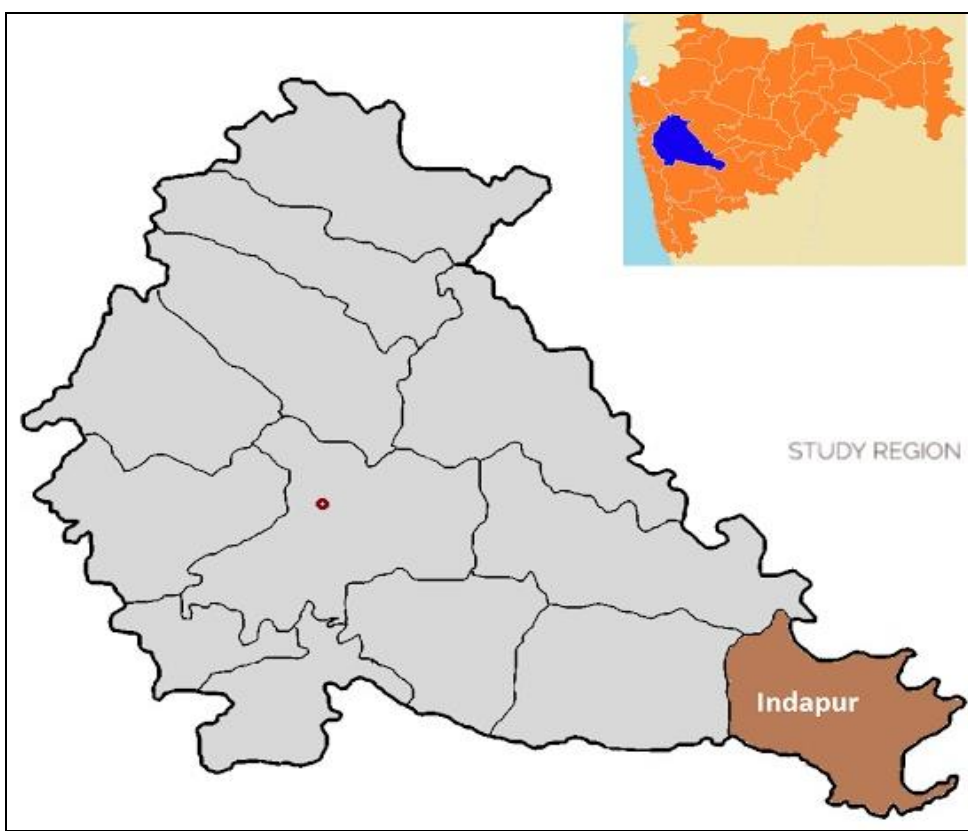

Map showing collection of molluscan sites shells from Ujani wetland area Indapur

\section{Results and Discussion}

Table 1: Number of genera and species of Molluscans families from Ujani wetland, Pune, Maharashtra, India

\begin{tabular}{|c|c|c|c|}
\hline Sr. No & Families & No. of Genus & No. of Species \\
\hline 1. & Achatinidae & 1 & 1 \\
\hline 2. & Cyrenoidae & 1 & 3 \\
\hline 3. & Lymnaeidae & 1 & 2 \\
\hline 4. & Melonidae & 1 & 1 \\
\hline 5. & Planorbidae & 1 & 1 \\
\hline 6. & Thiaridae & 2 & 3 \\
\hline 7. & Unionidae & 3 & 6 \\
\hline 8. & Viviparidae & 1 & 3 \\
\hline
\end{tabular}

Total 20 species under 11 genera and 08 families were recorded during the 6-month survey in Ujani wetland, Indapur. In our observation Unionidae is the most represented family with 06 species.

We observed 6 species belonging to family Unionidae, 3 species belonging to family Cyrenoidae, Thiaridae and Viviparidae respectively, 2 species of family Lymnaeidae, 1 species of family Achatinidae, Melonidae and Planorbidae (Table no. 1).

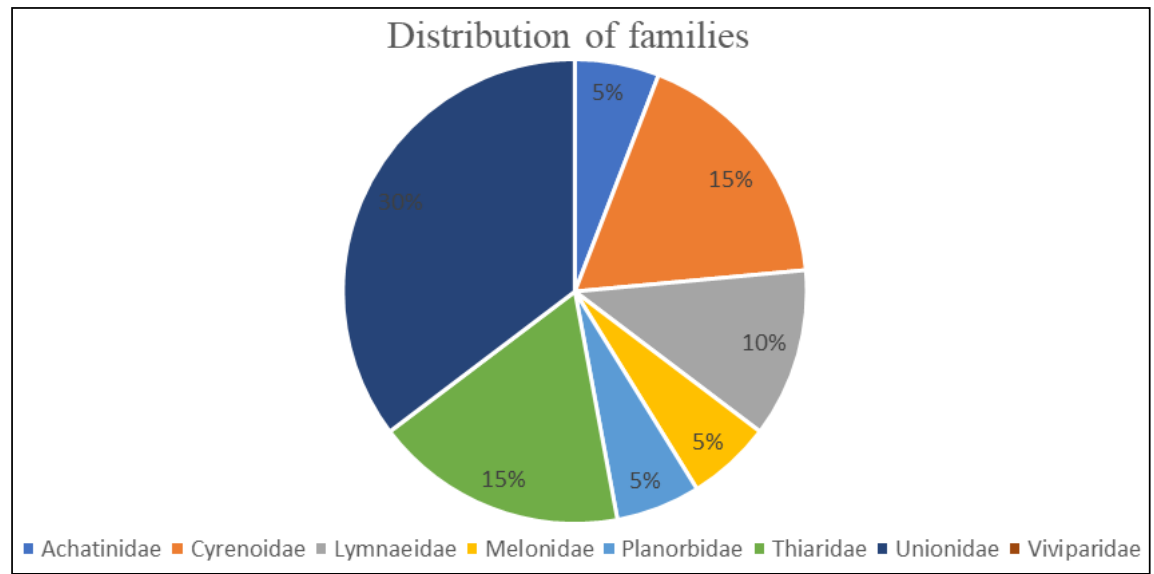

Fig 1: Percentage of family wise distribution 
Table 2: Showing Molluscan species with classification from Ujani Wetland, Indapur, Pune (MS)

\begin{tabular}{|c|c|c|c|c|}
\hline Sr. No & Class & Order & Family & Species \\
\hline \multirow{5}{*}{01} & \multirow{5}{*}{ Gastropoda } & \multirow{4}{*}{ Mesogastropoda } & Achatinidae & Archatina fulica (ferussac, 1821) \\
\hline & & & Viviparidae & $\begin{array}{c}\text { Ballamya bengalensis (Lamarck,1822) } \\
\text { Ballamya eburnea (Annandale, 1921) } \\
\text { Ballamya dissimilis (Muller, 1774) }\end{array}$ \\
\hline & & & Thiaridae & $\begin{array}{c}\text { Teberia granifera }(\text { Lamarck, 1822) } \\
\text { Teberia lineate }(\text { Gray, 1828) } \\
\text { Thiara scabra }(\text { Muller, 1774) }\end{array}$ \\
\hline & & & Melonidae & Melanoides tuberculata (Muller, 1774) \\
\hline & & Basommatophora & Lymnaeidae & $\begin{array}{l}\text { Lymanea acuminate (Lamarck, 1822) } \\
\text { Lymanea luteola (Lamarck, 1822) }\end{array}$ \\
\hline & & & Planorbidae & Endoplanorbis exustus (Deshyes, 1834) \\
\hline \multirow[t]{2}{*}{02} & \multirow[t]{2}{*}{$\begin{array}{c}\text { Pelecypoda } \\
\text { (Bivalvia) }\end{array}$} & Eulamellbrachiata & Unionidae & $\begin{array}{l}\text { Lamellidens corrianaus (Lea, 1819) } \\
\text { Lamellidens marginalis (Lamarck, 1822) } \\
\text { Parreysia corrugate (Muller, 1774) } \\
\text { Parreysia favidens (Benson, 1862) } \\
\text { Parreysia shurtleffiana (Lea, 1836) } \\
\text { Sphaerium indicum (Deshyes, 1834) }\end{array}$ \\
\hline & & Venerida & Cyrenoidae & $\begin{array}{c}\text { Corbicula peninsularis (Prashad,1928) } \\
\text { Corbicula striatella (Deshayes, 1854) } \\
\text { Corbicula fluminea (Muller, 1774) }\end{array}$ \\
\hline
\end{tabular}

\section{Discussion}

Molluscan are considered are the most diverse and dominant benthic fauna both from lentic and lotic region which are mainly represented by the two major classes namely Gastropods and Pelecypods ${ }^{[4]}$. Published the checklist of the land and fresh water molluscan of Maharashtra state reported, 142 species of molluscan of all forms belonging to 42 genera including 23 families. Amitkumar have observed 18 Gastropod species and 7 Pelecypod species from north Bihar region of India ${ }^{[4]}$. Studied the existence of freshwater bivalve molluscs from Pusad region of Yavatmal district, (Maharashtra) ${ }^{[3]}$. Studied the molluscan diversity from the Ujain wet land region ${ }^{[6]}$. Have reported the biodiversity of aquatic animal including some molluscs from Ruti reservoir near Asthi, district Beed (Maharashtra) and identified two orders and three genera of mollusca studied the diversity of fresh freshwater molluscs from Chincholi tank near Sangola and reported, 12 species of molluscs ${ }^{[7]}$.

In the present study, 20 species of molluscs belong to class gastropoda and bivalvia were recorded from five different spots of Ujani wetland area, Indapur, Pune, Maharashtra (table. No. 2). In the present study 11 species from class, gastropoda belongs to 02 orders, 06 families and 07 genera awere recorded. From class bivalvia, 09 species belong to 02 orders, 02 families and 04 genera were recorded (Table No. 2). A large number of species were recorded from class gastropoda includes 11 species. Order mesogastropods consists of species (08) followed by basommatophoran (03). From class bivalvia, Order Eulamellbrachiata consist of species (06) followed by Venerida (03)

\section{Conclusion}

During study altogether 20 species of Mollusca belonging to 11 genera, under 08 families were recorded. This information of freshwater Molluscs from Ujani wetland area, Indapur, Pune (Maharashtra). There is a quiet need for comprehensive study of freshwater Mollusca from the Ujani wetland region. Further, extensive surveys of this area will definitely make known the presence of voluminous species than what is known today.

\section{References}

1. Subba Rao NV, Mitra SC. On collections of Mollusca from Poona and adjacent districts. Newsletter of the Zoological Survey of India 1975;1(4):77-79.

2. Subba Rao NV, Mitra SC. On land and freshwater Molluscs of Pune district, Maharashtra. Records of the Zoological Survey of India 1979;75:1-37.

3. Surya Rao KV, Mitra SC, Mitra S. Mollusca of Ujani wetland (wetland ecosystem) Series 2: Fauna of Ujani, Zoological survey of India. Kolkata 2002, 110-115.

4. Patil SG. Occurance of freshwater Bivalve (Bivalvia: Unionidae) in Pusad. Yavatmal. District. Maharashtra. Zoos Print. Journal 2003;18(a):11-95.

5. Ramakrishnaanirudha Dey Handbook on Indian Freshwater Molluscs Zoological Survey of India, MBlock, New Alipore, Kolkata.

6. Kamble VS, Rao KR. Molluscan diversity from freshwater reservoir at Chincholi, (Sangola) dist. Solapur, Maharashtra, (India). Bionano frontier journal of science and Biotechnology 2009. ISSN0974-0678.

7. Kamble NA, Kamble SB. Effect of lead acetate toxicity on biochemical components from select tissue in the snail, Bellamya bengalensi. J Aqua. Biol 2010;25(1):144-150. 